\title{
The life cycle of Anguillicola crassus
}

\author{
D. De Charleroy, L. Grisez, K. Thomas, C. Belpaire, F. Ollevier \\ Laboratory for Ecology and Aquaculture, Zoological Institute, Catholic University of Leuven, \\ Naamsestraat 59, B-3000 Leuven, Belgium
}

\begin{abstract}
For some years now the parasitic swim bladder nematode Anguillicola crassus of the European eel Anguilla anguilla L., has been reported from several European countries. The entire life history of this parasite has recently been elucidated in our laboratory. Young larvae leave the swim bladder of the host via the pneumatic duct and reach the water through the digestive tract. They are ingested by small copepods (Cyclopoida), which act as intermediate hosts. Larvae remain in the hemocoel until the copepods are eaten by the final host, the European eel. Larvae penetrate through the intestinal wall and reach the swim bladder where they develop into adults. When infected copepods are eaten by other small fish, such as carp Cyprinus carpio L. or ide Leuciscus idus L., larvae do not reach the adult stage. However, when larger eels feed on such facultative reservoir hosts, they too become infected.
\end{abstract}

\section{INTRODUCTION}

Anguillicola crassus, a parasitic swim bladder nematode of the European eel Anguilla anguilla, was first observed in Belgium in December 1985 (De Charleroy 1986). This parasite, originating from South East Asia (Kuwahara et al. 1974), probably reached Western Europe in the early eighties via the import of infected eel for consumption or restocking (Peters \& Hartmann 1986, Belpaire et al. 1989a, b). Very soon, it was apparent that this parasite had spread quickly through several countries, not only causing problems to eel growers, but also infecting a rapidly increasing percentage of the natural eel populations (Paggi et al. 1982, Neumann 1985, Peters \& Hartmann 1986, Van Banning et al. 1986, Dupont \& Petter 1988). This phenomenon made it imperative to study the life cycle of $A$. crassus in our region, with special attention being paid to the intermediate hosts.

According to Chabaud (1965), nematodes from the suborder Camallanata always use a crustacean as intermediate host, often a copepod. Wang \& Zhao (1980) noticed that several species of copepods are able to carry the infective stage of the parasite Anguillicola globiceps to the final host. De Charleroy et al. (1987) found that all of 10 Cyclopoida species tested were able to take up A. crassus larvae and carry them in their hemocoel. The species involved were: Paracyclops fimbriatus, Macrocyclops albidus, M. fuscus, Eucyclops serrulatus, E. macruroides, Cyclops strenuus, C. vicinus, Acanthocyclops robustus, A. vernalis and Diacyclops bicuspidatus.

Although copepods are not considered a main food item for eels, they are eaten by younger individuals (Lecomte-Finiger 1983, De Nie 1987) and as the eels grow, the size of their prey increases (Neveu 1981). According to Tesch (1977) the proportion of fish found in the stomach of the eels increases with length, and from a certain length on $(40$ to $50 \mathrm{~cm}$ ) they show feeding patterns typical of piscivorous predators. The largest eels $(>50 \mathrm{~cm})$ feed almost exclusively on fish.

In nature, small eels as well as larger ones seem to become infected by Anguillicola crassus. According to Peters \& Hartmann (1986) eels become already infested after they reach a length of about $20 \mathrm{~cm}$ and a weight of ca $10 \mathrm{~g}$ and as the eels grow, the frequency of infestation increases. Larval Stage 3 and 4 are also frequently found in the swim bladder of larger eels, which are believed not to feed regularly on such small prey. Referring to Barus \& Rysavy (1973), who describe the different forms and prevalence of reservoir habitationism in Nematoda, we tried to find out if the transfer of $A$. crassus from any other fish to eel was possible. 


\section{MATERIAL AND METHODS}

Eels were obtained from our intensive eel culture at the Zoological Institute. They were cultured free from Anguillicola crassus parasites from the glass eel stage (originating from the Portuguese coast) onwards. A crassus larvae were recovered from specimens collected in Belgian ponds and rivers. The copepod species used in our experiments was Paracyclops fimbriatus, which could be obtained in large quantities because it is a typical species that thrives very well in freshwater intensive fish culture systems (recirculation at ca $25^{\circ} \mathrm{C}$ ), where other copepods do not seem to occur. In this case it was possible to collect a pure batch of $P$. fimbriatus.

Fish species tested for their capacity to act as reservoir hosts were carp Cyprinus carpio L. and ide Leuciscus idus L. originating from a fish culture.

Collection of larvae. By dissection of infected eels, large numbers of eggs containing $\mathrm{L}_{2}$ larvae were obtained from the swim bladder. These larvae were used in the following steps.

Infection of intermediate host. In order to infect the intermediate host, Paracyclops fimbriatus were kept at $21{ }^{\circ} \mathrm{C}$ and fed with a number of newly hatched Anguillicola crassus larvae. According to Thomas \& Ollevier (1989) only the copepodite and adult stages were able to take up larvae; the naupliar stages did not feed on them. They also described high mortalities of heavily infected copepods. Therefore, we tried to administer ca 2 to 3 times as many larvae as there were copepods. Infection of copepods was verified by dissection, and larval growth and moulting into the $\mathrm{L}_{3}$ stage was investigated.

Infection of final host. Because of the small size of the copepods (ca $0.8 \mathrm{~mm}$ long) young elvers were used for infection tests. In a first experiment, 20 elvers (mean weight $1.62 \mathrm{~g}$, mean length $9.2 \mathrm{~cm}$ ) were held in an aquarium for 2 mo and accustomed to feed on noninfected copepods; one elver died during this adaptation period. On the day of infection, elvers were fed a large amount (ca 1000 specimens) of infected Paracyclops fimbriatus, over a $24 \mathrm{~h}$ period. It was impossible to count how many copepods each eel consumed. The fish were dissected 40 d later.

In a second experiment 42 glass eels (mean weight $0.14 \mathrm{~g}$, mean length $6.4 \mathrm{~cm}$ ) were fed with Paracyclops fimbriatus containing $\mathrm{L}_{3}$ larvae for $24 \mathrm{~h}$. Thirty five days later 30 glass eels were examined for the presence of Anguillicola crassus. The remaining glass eels were used in subsequent experiments.

Infection of reservoir hosts and final hosts. From a batch of small fish, 20 specimens (10 ide and 10 carp) (ca $2 \mathrm{~cm}$ long) were taken for the following experiment. Five fish of each species were immediately verified for
Anguillicola crassus infection. The 10 remaining fish 15 ide and 5 carp), which were adapted to eat copepods. were fed infected Paracyclops fimbriatus. Five days later 6 of the 10 remaining fish ( 3 of each) were administered, by forced feeding, to 6 uninfected eels (ca $150 \mathrm{~g}$ ). To force feed eels were first anaesthetisized then an infected fish was placed into a plastic tube which was inserted directly into its stomach and pushed into the stomach by means of a small rod. Two eels were each dissected after 1,2 and 4 mo (so all 6 eels were examined) and examined for swim bladder infection.

One carp and 1 ide were dissected and examined for Anguillicola crassus infection 15 and $60 \mathrm{~d}$ after feeding copepods to smaller fish.

Forty-four days after their infection, 12 infected glass eels were force fed to 3 uninfected eels weighing ca 50 $g$ (i.e. 4 glass eels/eel). Two weeks later these eels were dissected and the presence of Anguillicola crassus verified.

Release of eggs and larvae from swim bladder. In order to verify whether the pneumatic duct functions as a possible way out for larvae, infected eels were placed in a Büchner flask half full of water. Atmospheric pressure was then artificially decreased, and the presence of larvae in the upper part of the intestinal tract investigated.

\section{RESULTS AND DISCUSSION}

\section{Larvae of Anguillicola crassus}

In a few cases copulating nematodes were observed in swim bladders from eels infected with adult Anguillicola crassus. The liquid present in these swim bladders regularly contained tens of thousands of eggs, (mean length $90 \mu \mathrm{m}$, mean width $75 \mu \mathrm{m}$ ) containing $\mathrm{L}_{2}$ larvae. Already in the uteri of the fecundated females, $L_{1}$ larvae moulted into $L_{2}$ larvae. At oviposition, $L_{2}$ larvae were present in the eggs of the parasite, still surrounded by the loose $\mathrm{L}_{1}$ cuticle. In the swim bladder most of the $\mathrm{L}_{2}$ larvae remained in the egg capsule, although a small percentage of larvae had already hatched (Figs. 1 and 2).

\section{Intermediate host infection}

Eggs containing $\mathrm{L}_{2}$ larvae brought into contact with freshwater hatched within a few hours at room temperature (ca $21^{\circ} \mathrm{C}$ ). Such larvae were used to infect Paracyclops fimbriatus. As expected $P$. fimbriatus fed with $\mathrm{L}_{2}$ carried A.crassus larvae in their hemocoel (mean 4.9 larvae copepod ${ }^{-1}$ ). Compared with free living $L_{2}$ larvae 


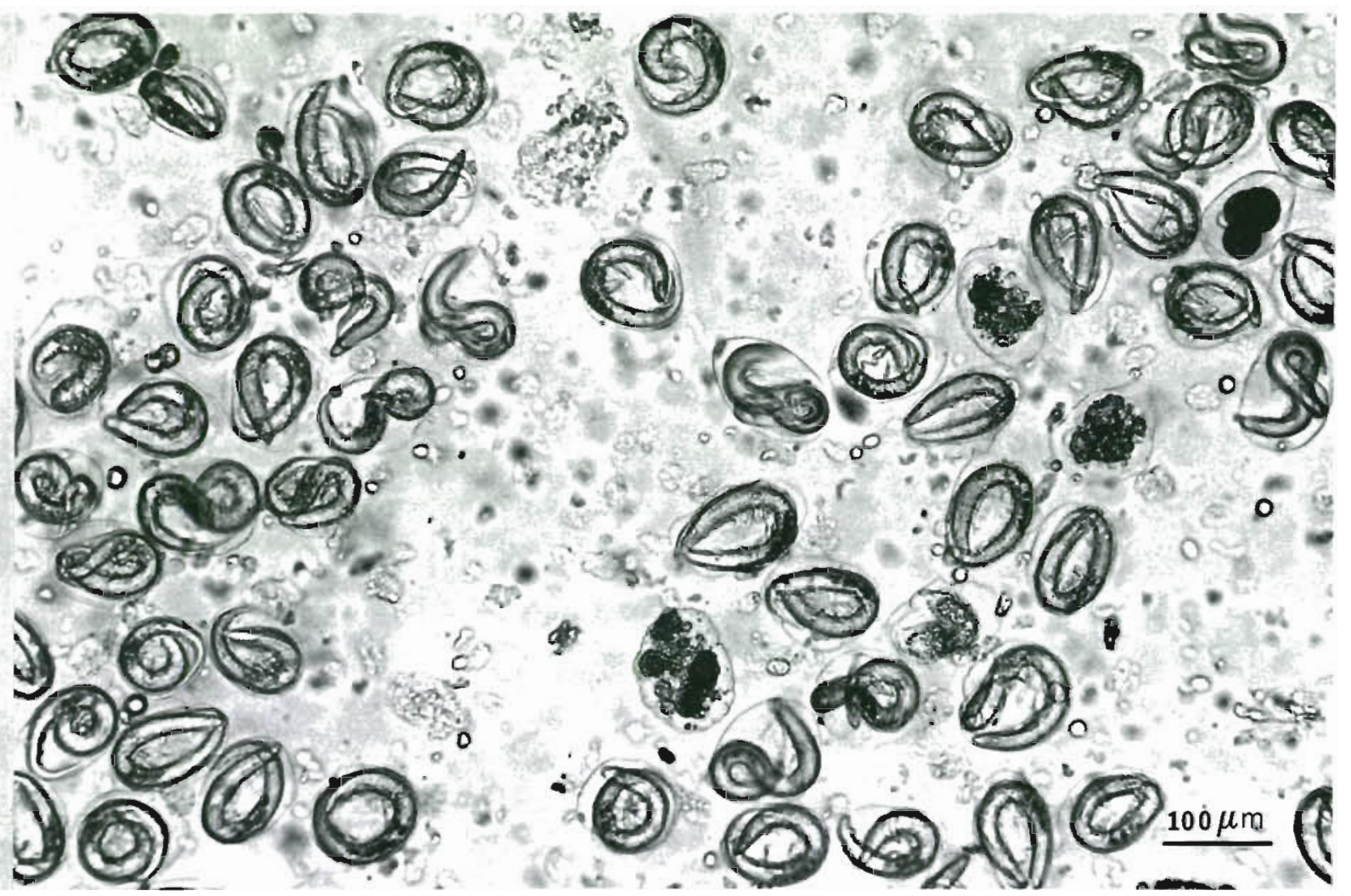

Fig. 1. Anguillicola crassus $\mathrm{L}_{2}$ as they can be found in the swim bladder of an infected eel. They are still surrounded by their egg sheath and the $\mathrm{L}_{1}$ cuticle

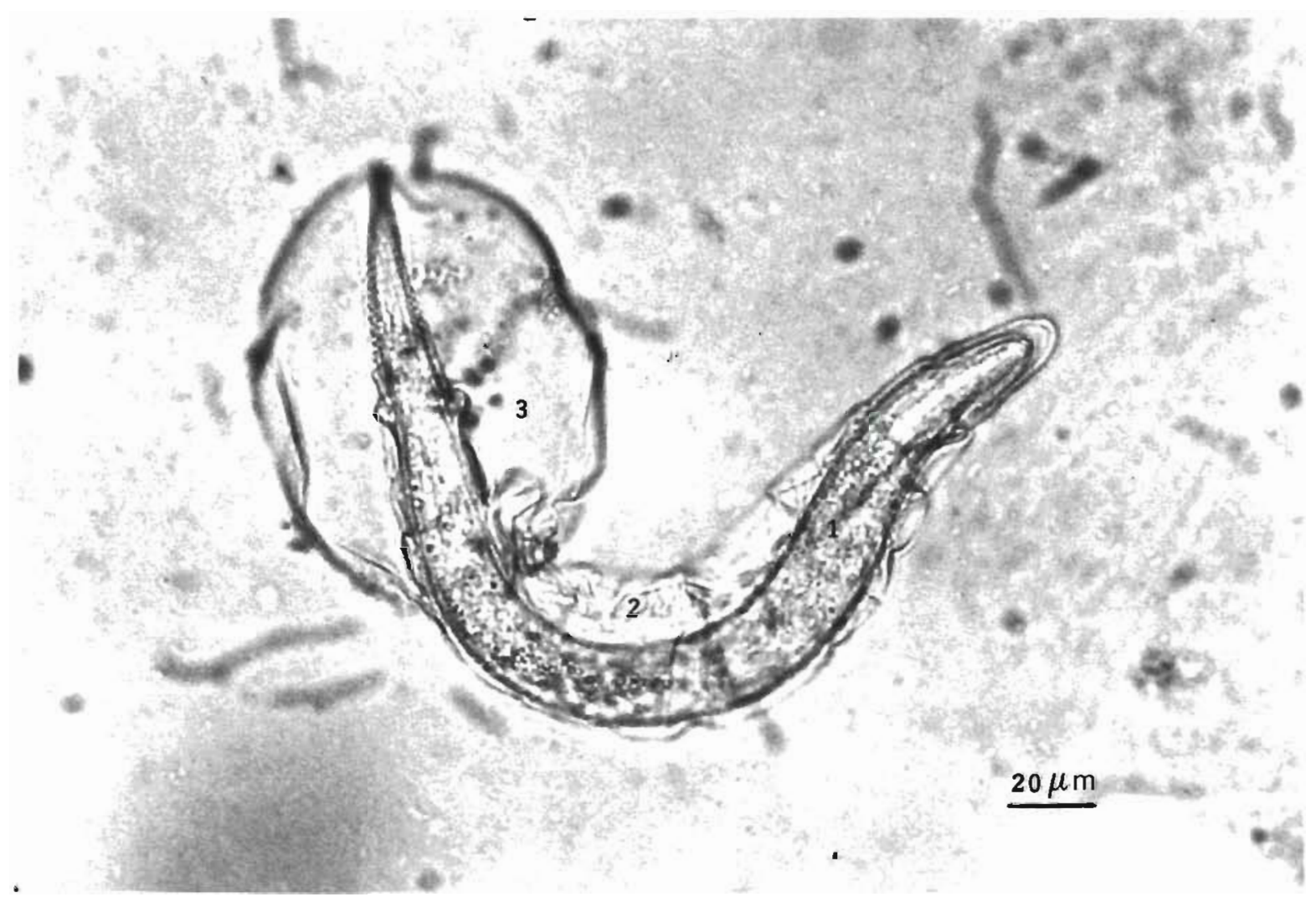

Fig. 2. Anguillicola crassus. Hatching of an $\mathrm{L}_{2}$ from the egg. The larva (1), loose $\mathrm{L}_{1}$ cuticle (2) and egg sheath (3) are clearly visible 


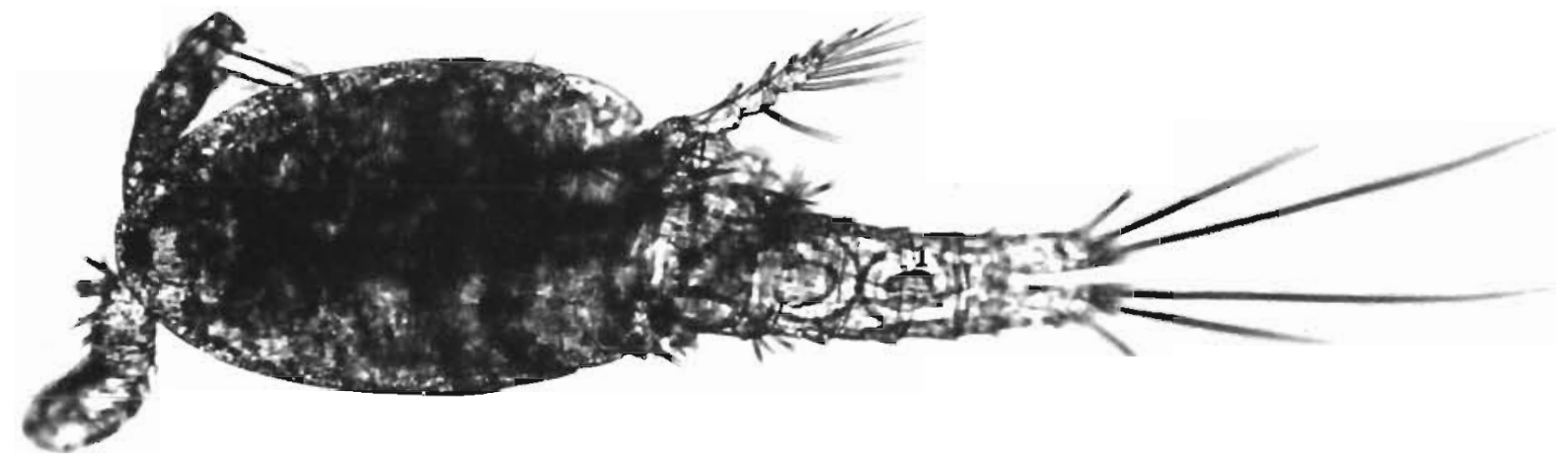

Fig. 3. Anguillicola crassus. Paracyclops fimbriatus (intermediate host) infected with larvae (1) which are visible in the abdomen

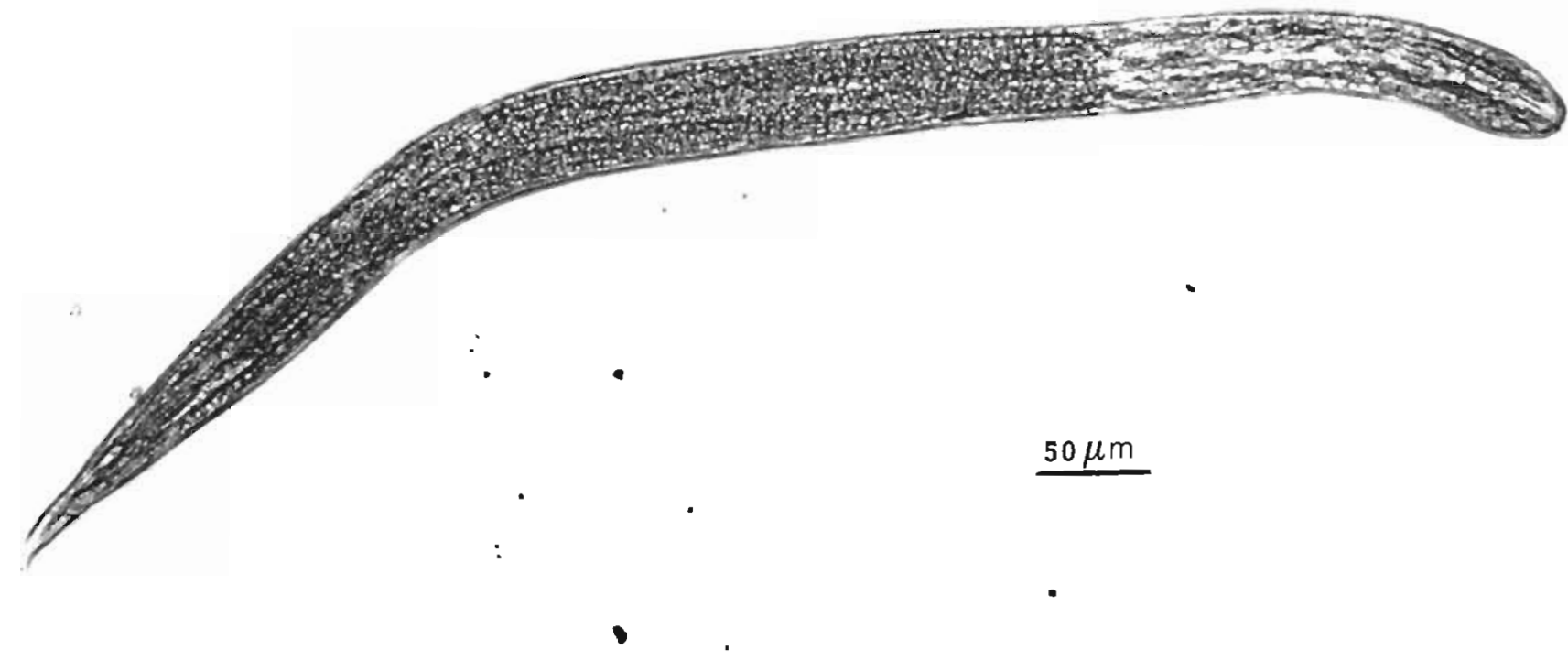

Fig. 4. Anguillicola crassus. $\mathrm{L}_{3}$ larvae dissected out of the intermediate host Paracyclops fimbriatus $10 \mathrm{~d}$ after infection with $\mathrm{L}_{2}$ larvae. Moulting has already taken place 
(mean length $250 \mu \mathrm{m}$, mean width $18 \mu \mathrm{m}$ ), no growth was observed during the first days post-infection, as a matter of fact, larvae became smaller during the first $3 \mathrm{~d}$ but from Day 4 , larvae steadily started growing. Between Days 10 and 12 moulting to the $\mathrm{L}_{3}$ stage (Figs. 3 and 4) took place (mean length $716 \mu \mathrm{m}$, mean width $37 \mu \mathrm{m}$ )

\section{Final host infection}

Eighteen of the 19 elvers infected with copepods carrying $\mathrm{L}_{3}$ larvae contained young Anguillicola crassus in their swim bladder (range 4 to 357, mean 99). Since we could not verify how many copepods each elver ate these numbers were of little quantitative value to demonstrate the infection efficiency, although it is worth mentioning for its qualitative value. Preliminary experiments using Paracyclops fimbriatus containing $\mathrm{L}_{2}$ larvae for 1 or $7 \mathrm{~d}$ gave poor infection percentages ( 5 to $9 \%$ ); we had expected completely negative results.

In the second experiment 26 of 30 glass eels contained young parasites (mean 3.3, max. 22). This indicates that even the very young glass eel stages can be infected. In those glass eels where the swim bladder was still very small, $\mathrm{L}_{3}$ larvae remained in the body cavity instead of penetrating into the swim bladder wall.
Table 1. Anguillicola crassus number in swim bladder of 6 eels, each previously fed with one infected fish

\begin{tabular}{|ccll|}
\hline Eel no. & $\begin{array}{c}\text { Post- } \\
\text { infection } \\
\text { (d) }\end{array}$ & Fish & \multicolumn{1}{c|}{ Stage } \\
\hline 1 & 30 & Ide & 1 larva \\
2 & 30 & Carp & 72 larvae \\
3 & 60 & Ide & 11 preadults \\
4 & 60 & Carp & 2 adults \\
5 & 120 & Ide & Not infected \\
6 & 120 & Carp & adults, large no. of eggs \\
& & & \\
\hline
\end{tabular}

\section{Reservoir and final host infection}

The 10 control ide and carp examined, before the start of the experiment, all were negative. In the 10 infected fish no Anguillicola crassus were found in the swim bladder. Living $L_{3}$ larvae of $A$. crassus were found free in the body cavity of all fish examined 15 and $60 \mathrm{~d}$ post-infection.

Five of the 6 eels fed with these $\mathrm{L}_{3}$ infected ide and carp, contained Anguillicola crassus (Table 1). We have no indications why these $\mathrm{L}_{3}$ larvae remained in the body cavity of ide and carp, although it could be linked to the developmental stage of their swim bladder. In

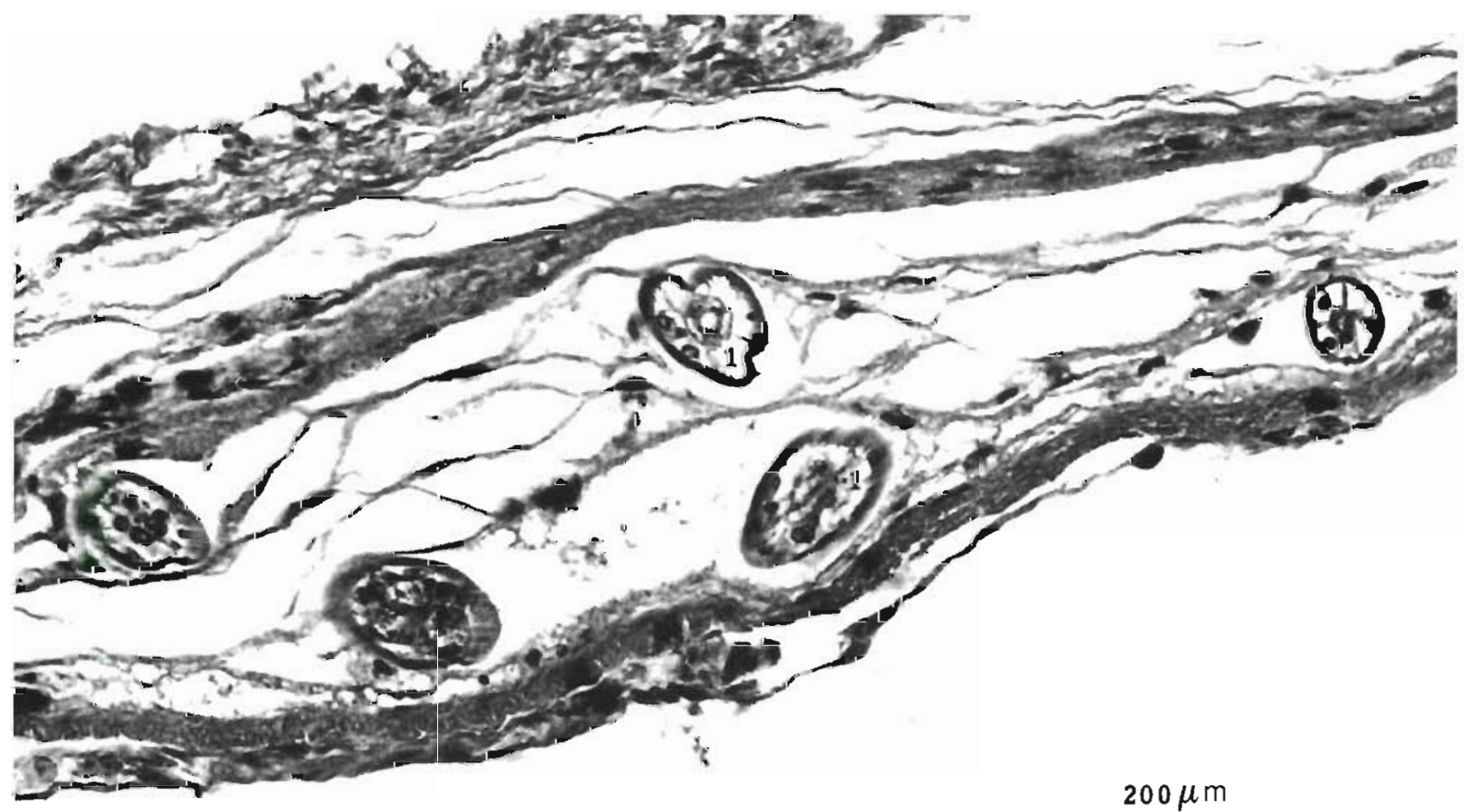

Fig. 5. Anguillicola crassus. Sections of L, larvae (1) in the submucosa of the swim bladder of eel Anguilla anguilla where they pass during their migration to the swim bladder lumen ( $\mathrm{H} \& \mathrm{E}$ staining) 


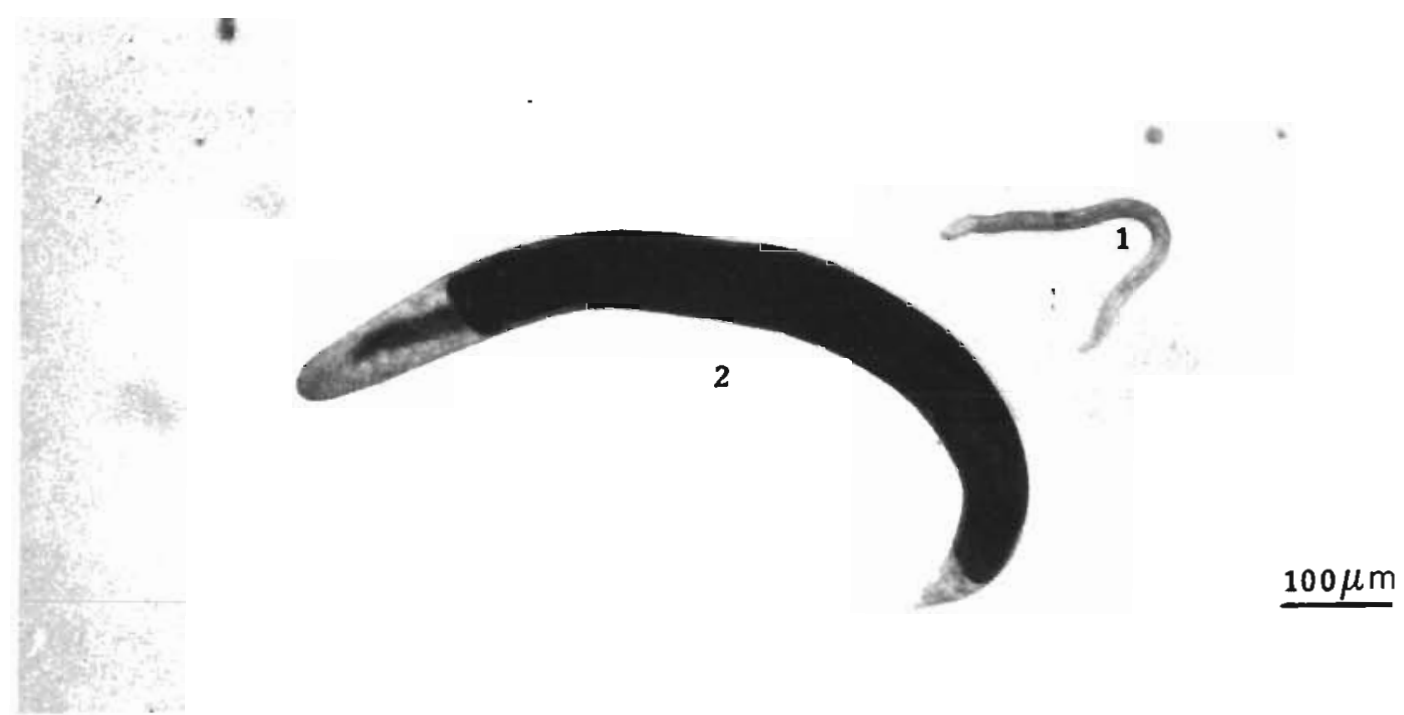

Fig. 6. Anguillicola crassus. The difference between $L_{3}(1)$ and $L_{4}(2)$ larvae is clearly visible. The $L_{4}$ larvae are considerably larger and are stained darkly

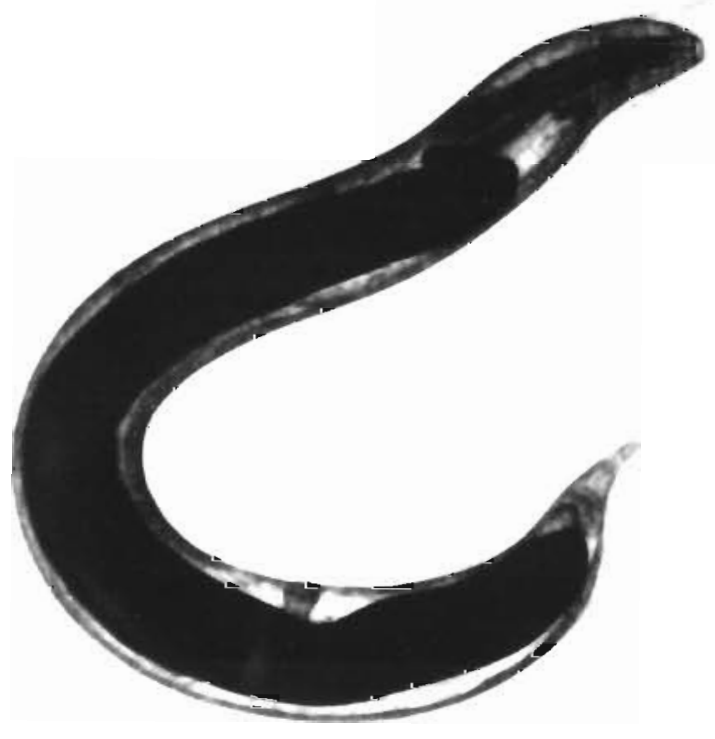
visible at the head end of the parasite (1) 
carp samples taken from Belgian ponds and rivers, $\mathrm{L}_{3}$ larvae were found in the body cavity as well as in the swim bladder. In perch Perca fluviatilis and pumpkinseed Lepomis gibbosus from field samples taken in Belgium, $\mathrm{L}_{3}, \mathrm{~L}_{4}$ and even preadult stages were found in the swim bladder. However, these preadults exhibited an atypical morphology and would probably never have reached sexual maturity (Cannaerts 1989). Belpaire et al. (1989b) found 3-spined sticklebacks Gasterosteus aculeatus infected with $A$. crassus larvae in the swim bladder wall (River Yser, Belgium).

After infection of eels, the relatively mobile $\mathrm{L}_{3}$ larvae did not immediately penetrate the lumen of the swim bladder but remained in the submucosa (Fig. 5). There they developed into the less mobile $\mathrm{L}_{4}$ larvae (Fig. 6), which required just over 2 wk under our experimental conditions. These larvae were bigger and stained darkly, due to the presence of blood in their digestive system. After the last moult (Fig. 7) preadults (the gonadal system of which was not yet functioning) were found in the swim bladder cavity. Sexes of the parasites can easily be distinguished in the adult stages. The seminal vesicle is well defined in male parasites, whereas in female Anguillicola crassus the uteri and the vulva are clearly visible.

The 3 eels fed with infected glass eels $2 \mathrm{wk}$ earlier contained $9 \mathrm{~L}_{4}, 12 \mathrm{~L}_{3}$ and $7 \mathrm{~L}_{4}$ Anguillicola crassus larvae in the wall of their swim bladder, respectively.

\section{Release of eggs and larvae from the swim bladder}

Shortly after an abrupt, artificial decrease in atmospheric pressure, large amounts of eggs were found in the upper region of the digestive tract of infected eel, indicating that the pneumatic duct probably serves as a route for Anguillicola crassus to passively leave the swim bladder. In the intestinal tract of infected eel, $A$. crassus eggs as well as free living $L_{2}$ stages were regularly observed; these are passed with the feces into the water

\section{LIFE HISTORY OF ANGUILLICOLA CRASSUS}

The results presented here and other preliminary experiments allow us to give a more complete overview of the life cycle of Anguillicola crassus. Copulation between adult male and female parasites takes place in the swim bladder of the final host, the eel. The fertilized eggs develop in the female reproductive system and thus contain $\mathrm{L}_{2}$ larvae at the moment of oviposition. Most of the larvae remain in the egg during their stay in the swim bladder, which they subsequently leave via the pneumatic duct, probably passively.
During or after passage through the digestive tract hatching occurs and $\mathrm{L}_{2}$ larvae emerge from the eggs; the cuticula of the $L_{1}$ larvae forming a loose sheath surrounding the $\mathrm{L}_{2}$ stage. These free-living $\mathrm{L}_{2}$ larvae (ca $250 \times 18 \mu \mathrm{m}$ ) fasten themselves by their tail-end to the substratum and wriggle their body intensively. This behaviour presumably stimulates predation by copepods. At this stage, larvae can stay alive up to 1 mo depending on external factors such as salinity and temperature (De Charleroy et al. 1989).

When eaten by a suitable intermediate host, larvae ensconce themselves in the hemocoel and start growing after a few days. The larvae moult in the copepod and reach the third and infective stage $\left(\mathrm{L}_{3}\right)$ after 10 to $12 \mathrm{~d}$ (at $21^{\circ} \mathrm{C}$ ) (Thomas \& Ollevier 1989). Eels eating such infected copepods can become infected from the glass-eel stage onwards. When these infected copepods are eaten by small fish e.g. carp or ide, the $\mathrm{L}_{3}$ larvae remain alive in the fish. These small reservoir hosts can be eaten by bigger eels, which thus become infected (Grisez 1988).

From the lumen of the eel intestine the $L_{3}$ larvae reach the swim bladder wall by passing through the intestinal wall and the body cavity (Haenen et al. 1989).

Nematodes moult to $\mathrm{L}_{\mathbf{4}}$ after 2 to $3 \mathrm{wk}$ in the swim bladder, suck blood and grow. They moult again, grow further, become sexually mature and commence reproducing in the swim bladder cavity. Under laboratory conditions (at $20^{\circ} \mathrm{C}$ ) the complete life cycle can take less than 2 mo.

It is easier to understand the exponential spread of Anguillicola crassus in Europe during recent years when taking into account the large quantities of $A$. crassus eggs found in the swim bladder of an infected eel (sometimes originating from a single pair of adults), the rather short period needed to complete the life cycle and the often careless import, export and restocking for commercial purposes.

Acknowledgements. This research was supported by grant no 2.0081.87 of the National Fund for Scientific Research (Belgium) and a research grant from the Catholic University of Leuven to Prof. Dr F.Ollevier. The authors would like to thank Dr F.Fiers for his help with the determination of the copepods, Dr F.Puylaert for the stimulating discussions, Dr F. Volckaert for correction of the English, Mrs J. Puttemans for the development of the pictures and AROL (Administration for Planning and Environment), Department of Freshwater Fisheries for their support and supply of infected eels.

\section{LITERATURE CITED}

Barus, V., Rysavy, B. (1973). Forms and prevalence of reservoir habitationism in Nematoda. Helminthologia 14: 401-419

Belpaire, C., De Charleroy, D., Grisez, L., Ollevier F. (1989a). Spreading mechanisms of the swim bladder nematode 
Anguillicola crassus in the European eel Anguilla anguilla, and its distribution in Belgium and Europe. European Inland Fisheries Advisory Commission (FAO). Working Party on Eel. Porto, Portugal, May 29th - June 3rd 1989

Belpaire, C., De Charleroy, D., Thomas, K., Van Damme, P., Ollevier, F.( 1989b). Effects of eel restocking on the distribution of the nematode Anguillicola crassus in Flanders, Belgium. J. appl. Ichthyol. 5(3): 151-154

Cannaerts, V (1989). Interactie van Anguillicola crassus, met enkele typische reservoirgastheren en de eindgastheer, Anguilla anguilla. M. Sc. dissertation. Catholic University of Leuven, Belgium

Chabaud, A. G. (1965). Classe des Nématodes. Ordre des Ascarida. In: Grassé, P.P.(ed.) Traité de Zoologie, Tome IV, Fasc. III. Masson et Cie, Paris, p. 1035-1036

De Charleroy, D., (1986). Parasitologisch onderzoek van de Europese paling Anguilla anguilla L. M. Sc. dissertation. Catholic University of Leuven, Belgium

De Charleroy, D., Thomas, K., Belpaire, C. (1987). Problems concerning the species determination, biology and diagnostical methods of Anguillicola, a swim bladder nematode in the European eel (Anguilla anguilla L.). European Inland Fisheries Advisory Commission (FAO). Working Party on Eel. Bristol, UK, April 13-16 1987

De Charleroy, D., Thomas, K., Belpaire, C, Ollevier, F. (1989). The viability of the free living larvae of Anguillicola crassus. J, appl. Ichthyol. 5(3): 154-156

De Nie, H. W. (1987). Food, feeding periodicity and consumption of the eel Anguilla anguilla L. in the shallow eutrophic Tjeukemeer (The Netherlands). Arch. Hydrobiol 109: 421443

Dupont, F., Petter, A. J. (1988). Anguillicola, une épizootie plurispécifique en Europe. Apparition d' Anguillicola crassa (Nematoda, Anguillicolidae) chez l'Anguille europeene (Anguilla anguilla) en Camargue, Sud de la France. Bull. Fr. Pêche Piscic. 308: 38-41

Grisez, L. (1988). Studie van de parasitaire zwemblaasnematode Anguillicola crassus, bij de europese paling,

Responsible Subject Editor: Professor W. Körting, Hannover, F. R. Germany
Anguilla anguilla. M. Sc. dissertation. Catholic University of Leuven, Belgium

Haenen, O., Grisez, L., De Charleroy, D., Belpaire, C. Ollevier, F. (1989). Experimentally induced infections of the european eel (Anguilla anguilla, L.) with Anguillicola crassus (Nematoda, Dracunculoidea) and subsequent migration of the larvae. Dis. aquat. Org. 7.97-101

Kuwahara, A., Nimi, A., Itagaki, H., (1974). Studies on the nematode parasitic in the air bladder of eel. I. Description of Anguillicola crassa n. sp. (Philometridea, Anguillicolidae). Jap. J. Parasit. 23: 275-279

Lecomte-Finiger, R., (1983). Régime alimentaire des civelles et anguillettes (Anguilla anguilla) dans trois étangs saumatres du Rousillion. Bull. Écol. 14: 297-306

Neumann, W. (1985). Schwimmblasenparasit Anguillicola bei Aalen. Fischer und Teichwirt 11:322

Neveu, A. (1981). Variations saisonières et journalières de l'alimentation de l' anguille (Anguilla anguilla, L.) dans des conditions naturelles Oecologia. Appi. (Paris) 2: 99-116

Paggi, L., Orecchia, P., Minervini, R., Matiucci, S. (1982). Sulla comparsa di Anguillicola australiensis Johnston et Mawson 1940 in Anguilla anguilla del Lago di Bracciano. Parasitologia, Leningrad 24: 139-144

Peters, G., Hartmann, F. (1986). Anguillicola, a parasitic nematode of the swim bladder spreading among eel populations in Europe. Dis. aquat. Org. 1. 229-230

Tesch, F.W. (1977). The Eel: biology and management of anguillid eels. Chapman and Hall, London.

Thomas, K., Ollevier, F. (1989). Aspects of the life cycle of Anguillicola crassus. IV European Association of Fish Pathologists International Conference. Santiago de Compostela, Spain. September 24-28

Van Banning, P., Heermans, W., Van Willegen, J. A. (1986) Anguillicola crassa, een nieuwe aalparasiet in de Nederlandse wateren. Visserij 38: 237-240

Wang, P., Zhao, Y. (1980). Observations on the life history of Anguillicola globiceps (Nematoda: Anguillicolidae). Acta zool. sin. 26: 243-249

Manuscript first received: December 11, 1989

Revised version accepted: March 9, 1990 